\title{
Spatial Development and Economic Competitiveness of Yogyakarta Urban Area
}

\author{
Ratika Tulus Wahyuhana ${ }^{1, *}$ Hanna Amalia Putri ${ }^{1}$ Ryan Hidayat ${ }^{1}$ \\ ${ }^{1}$ Urban and Regional Planning, Universitas Teknologi Yogyakarta, 55285, Indonesia \\ "Corresponding author. Email: ratika.wahyuhana@staff.uty.ac.id
}

\begin{abstract}
Yogyakarta City has a high population density and is classified as a large city. During its development, the increase in population led to the development of a city that expanded beyond administrative boundaries. In addition, differences and concentrations of economic activities in Yogyakarta City indicate income inequality. The wider the area and the population will lead to a tendency for complexity of problems related to regional inequality and economic competitiveness. This study aims to examine the direction of development of the Yogyakarta urban area through the development of land use and economic competitiveness. This research uses quantitative research methods with quantitative descriptive analysis techniques. The results showed that in a period of 4 years, the subdistricts located in the hinterland of the Yogyakarta urban area, namely some of the subdistricts in Sleman Regency, experienced a builtup land growth of 251 ha. The analysis of economic competitiveness shows that the districts that have economic competitiveness from the primary, secondary and tertiary sectors are dominated by the hinterland sub-districts of the Yogyakarta urban area and the value of economic inequality in the urban Yogyakarta area is high, namely 0.94. Based on the analysis of the development of developed land and the analysis of economic competitiveness, it shows that the direction of development in the urban area of Yogyakarta is dominated by sub-districts located in the hinterland part of the northern part of Yogyakarta urban area.
\end{abstract}

Keywords: Competitiveness, Economic, Urban, Spatial.

\section{INTRODUCTION}

The still high development gap between regions and the increasing population are challenges in regional planning. The consequence of urban development is the tendency to shift urban functions to the suburbs (urban fringe), which is called the process of spreading urban physical features outward (urban sprawl). The next consequence is that the suburban area will undergo a spatial transformation process in the form of a land densification process and a socio-economic transformation as a further impact of the spatial transformation process [1]. Regional development can occur due to an increase in population and expansion of developed land.

Yogyakarta City is one of the big cities and growth centers in DIY with the main developing sectors being the secondary and tertiary sectors and the main activities of trade and services. The city of Yogyakarta as the center of this urban area has a population of approximately 417,744 administratively in 2017 [2]. The administrative map of the Yogyakarta Urban Area can be seen in Figure 1.

When compared with an area of around 3,186 hectares (relatively small), the development of Yogyakarta City is quite rapid with a population density of 12,513 people $/ \mathrm{km}^{2}$ [2]. Figure 2 show population data in the urban area of Yogyakarta. The highest population density is in the sub-districts of Umbulharjo and Kotagede as well as several sub-districts which are inland areas such as Ngaglik, Mlati, Ngemplak, and Godean. Yogyakarta Urban Area Population Growth 2014-2018 can be seen in Table 1.

Based on the average population growth, the highest is found in 2 sub-districts in Yogyakarta City and dominated in sub-districts located in the hinterland of Yogyakarta City (Ngemplak, Ngaglik, Gamping, Mlati Districts). Of the existing land uses, $65 \%$ of the land is used for settlements with only $2 \%$ available green open space. This limitation of land does not support the everincreasing development of the city, resulting in developments that go beyond administrative boundaries 
to surrounding areas such as Sleman Regency, which indicates the expansion of the Yogyakarta region to its surrounding areas. The development of the city which continues to expand has finally formed Yogyakarta City in which there are new growth centers besides the City of
Yogyakarta, namely the growth centers in the Depok, Ngaglik, Gamping, Ngemplak, and Mlati areas. The purpose of this study is to examine the spatial development and economic competitiveness of the Yogyakarta Urban Area.
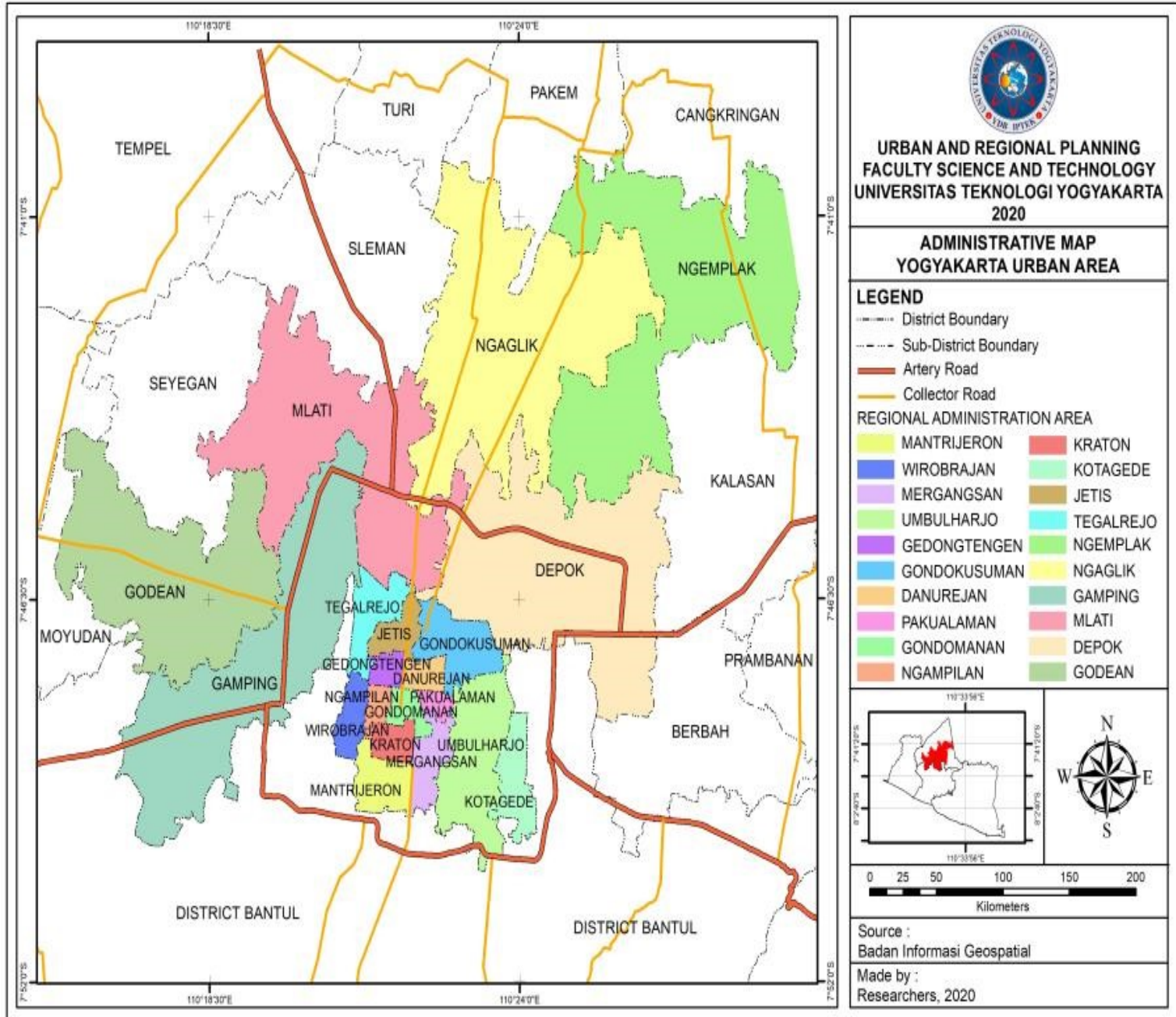

Figure 1 Yogyakarta urban area administration

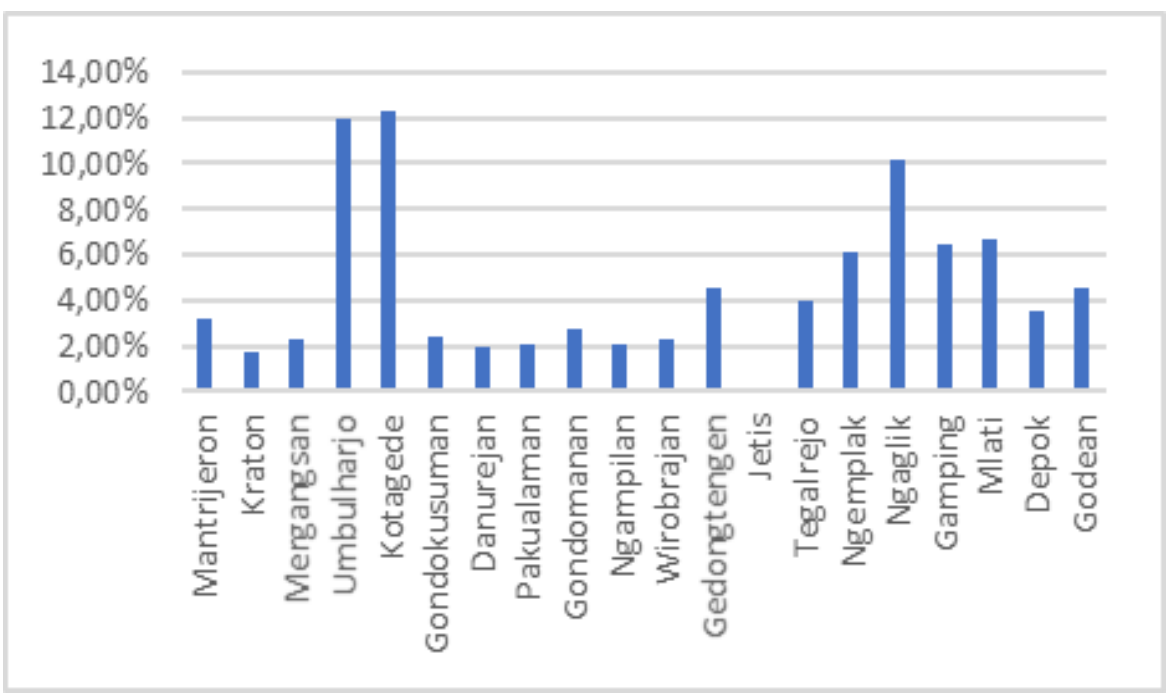

Figure 2 Population density 2014-2018 
Table 1. Yogyakarta Urban Area Population Growth 2014-2018

\begin{tabular}{ll}
\hline District & Average Population Growth \\
\hline Mantrijeron & $1,05 \%$ \\
Kraton & $0,56 \%$ \\
Mergangsan & $0,78 \%$ \\
Umbulharjo & $3,99 \%$ \\
Kotagede & $4,11 \%$ \\
Gondokusuman & $0,81 \%$ \\
Danurejan & $0,65 \%$ \\
Pakualaman & $0,67 \%$ \\
Gondomanan & $0,93 \%$ \\
Ngampilan & $0,67 \%$ \\
Wirobrajan & $0,76 \%$ \\
Gedongtengen & $1,53 \%$ \\
Jetis & $0,01 \%$ \\
Tegalrejo & $\mathrm{I}, 34 \%$ \\
Ngemplak & $2,05 \%$ \\
Ngaglik & $3,38 \%$ \\
Gamping & $2,14 \%$ \\
Mlati & $2,21 \%$ \\
Depok & $1,18 \%$ \\
Godean & $1,51 \%$ \\
Rate & $\mathbf{1 , 5 2 \%}$ \\
\hline &
\end{tabular}

\section{METHOD}

The research approach used is quantitative methods. Quantitative Research Methods are research methods based on the positivism philosophy, used to examine specific populations or samples, data collection using research instruments, statistical data analysis, with the aim of testing predetermined hypotheses [3]. The analysis used is an overlay of landsat land cover images, shiftshare analysis, and Williamson Index (IW) analysis. Land cover analysis is used to see the direction of development of developed land in the urban area of Yogyakarta in 2014-2018 and its area. Competitiveness analysis is used to determine the distribution of competitiveness per each district through the Regional Share Growth Component [4]. Furthermore, economic inequality analysis uses Williamson index analysis to determine the rate of inequality and the concentration of economic activity.

The data used are secondary data, namely visual data of 2014-2018 Landsat imagery and data on Gross Regional Domestic Product (PDRB) of each sub-district in the urban area of Yogyakarta.
Overlay analysis of landsat land cover imagery was used to compare built-up land in Yogyakarta urban area in 2014-2018. Shiftshare analysis through KPPW which is used to see regional competitiveness is described in the following formula:

Component Regional Share Growth $=$ (yit/yioYit/Yio) Information :

yit = national economic indicators for sector $\mathrm{i}$, year-end analysis / total PDRB sector $\mathrm{i}$ at level

2 in the final year of the analysis yio $=$ national area economic indicator sector i, early year analysis / number Gross Regional Domestic Product sector i at level 2 early analysis years

Yit $=$ national economic indicators for sector $\mathrm{i}$, end of year analysis / total Gross Regional Domestic Product sector $i$ at level 1 year end of analysis

Yio $=$ national economic indicators for sector $\mathrm{i}$, at the beginning of the analysis year / total Gross Regional Domestic Product sector i at level 1 in the initial year of analysis Economic inequality analysis using Williamson index analysis is described in the following formula : 


$$
\mathrm{Vw}=\frac{\sqrt{\sum\left(\mathrm{Yi}-\overline{\mathrm{Y}}^{2} \mathrm{fi} / \mathrm{n}\right.}}{\overline{\mathrm{Y}}}, 0<\mathrm{Vw}<1
$$

$\mathrm{Yi}=$ regional per capita income $\mathrm{i}$

$\mathrm{Y}=$ national cap income

$\mathrm{Fi}=$ population in the area $\mathrm{i}$

$\mathrm{N}$ = number of national population

$\mathrm{VW}=$ perfectly even

$\mathrm{Vw}-1=$ perfect inequality

If the Williamson gap index number gets closer to zero, it shows a smaller gap and if the index number shows getting closer to 1 (one) it shows a widening gap.
The criteria used to determine whether a gap is at a low, medium, or high level. The following are the criteria:

Low level gap, if IW $<0,35$

Medium level gap, if $0,35 \leq \mathrm{IW} \leq 0,5$

High level gap, if IW >0,5

\section{RESULT AND DISCUSSION}

\subsection{Analysis of the Spatial Development of the Yogyakarta Urban Area}

The spatial development of the Yogyakarta urban area was identified based on the area of land use built in 2014-2018 and its development in the suburb / hinterland which is directly adjacent to the city of Yogyakarta, namely in parts of Sleman Regency.

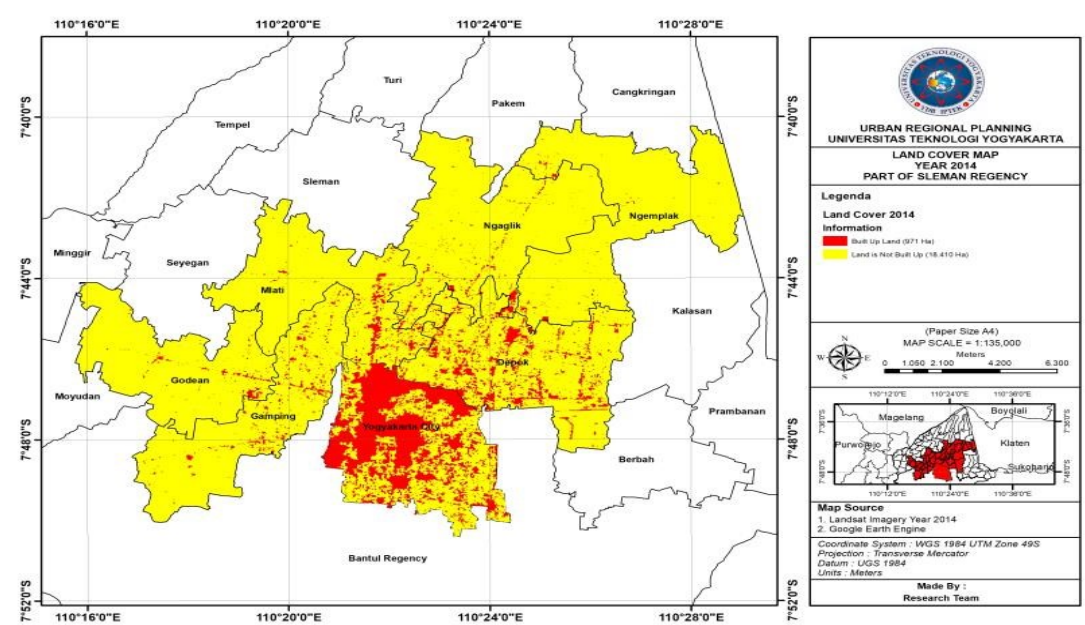

Figure 3 Built up urban area Yogyakarta 2014

The development of land developed in 2014 in the outskirts of Yogyakarta City, amounting to 971 ha. The built-up land consists of various functions ranging from settlements, offices, and built-up land for commercial activities.

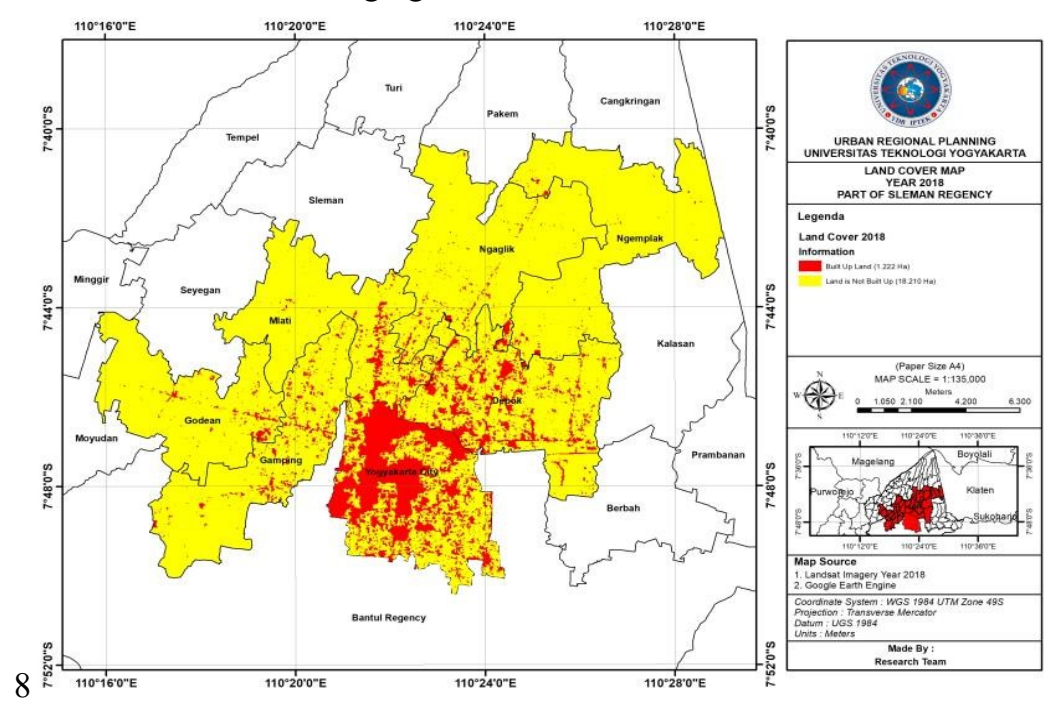

Figure 4 Built up urban area Yogyakarta 2018 
The development of developed land in 2018 in the suburbs of Yogyakarta City increased from the previous year which was 1,222 ha. The built-up land consists of various functions ranging from settlements, offices, and built-up land for commercial activities.

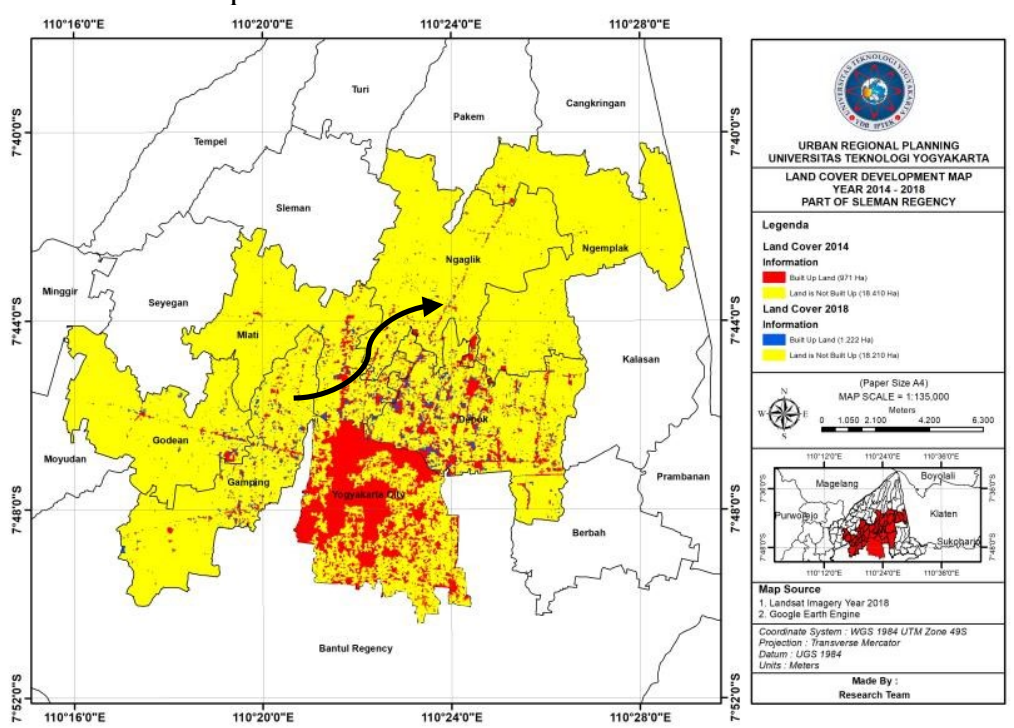

Figure 5 Built up urban area Yogyakarta 2014-2018

Based on the results of the analysis, land use built from 2014-2018 increased the area of built land by 251 ha. The condition of the built-in land in Yogyakarta City is already very dense, so it leads to the northern area, namely the inland area of Yogyakarta City, which is in Sleman Regency. The process of urban expansion into suburban areas which results in physical changes, for example changes in land use, demography, ecological balance and socio-economic conditions [1].

\subsection{Economic Disparity Analysis}

Economic disparity in the urban Yogyakarta area is high, namely 0.91 in 2012 and 0.96 in 2016. In a period of 4 years, economic inequality has increased by 0.05 which can be seen in the figure below :

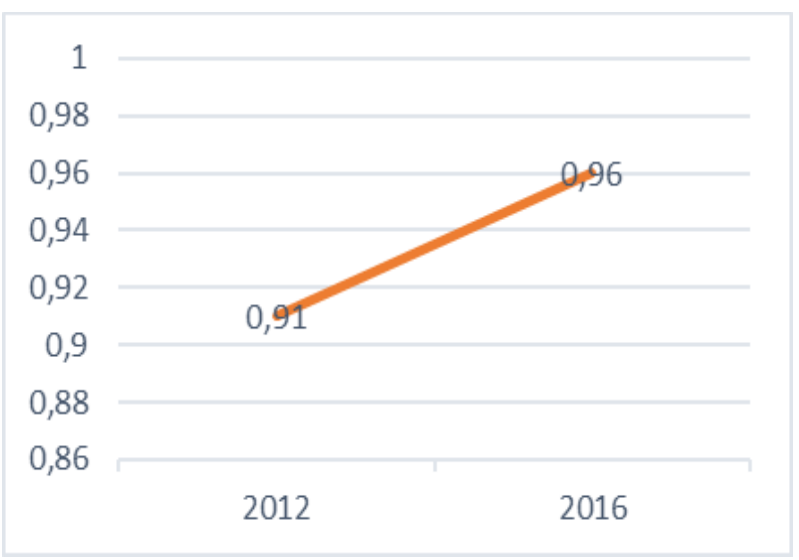

Figure 6 Economic disparity Yogyakarta urban area 2012-2016

This economic imbalance indicates a concentration of economic activity in the urban area of Yogyakarta.
Economic inequality between regions is caused by the imbalance of economic growth in each region. Thus, efforts are needed to reduce spatial inequality by balancing development in the city center and the hinterland in an integrated manner [1]. The distribution of per capita income from Gross Regional Domestic Product by capita from each district can be seen in the following figure :

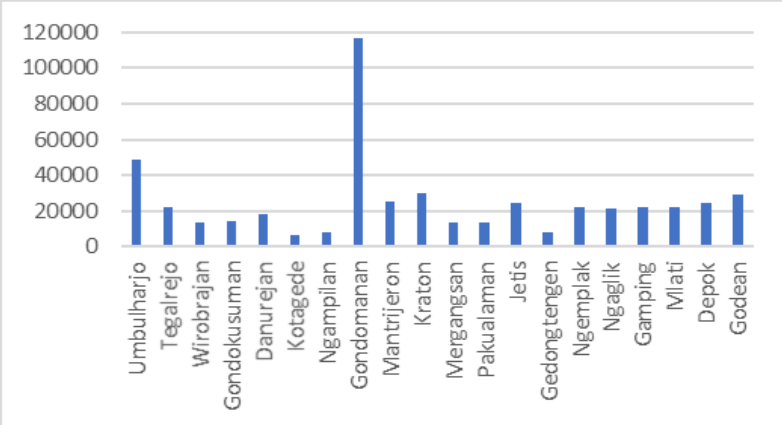

Figure 7 Yogyakarta urban area by capita income distribution

Based on the figure, it is known that the distribution of regional income through the Gross Regional Domestic Product data is uneven / unbalanced. This imbalance can be seen from the per capita GRDP between regions. The highest Gross Regional Domestic Product per capita was found in Gondomanan district with a value of 11,718,564 and the lowest Gross Regional Domestic Product per capita was found in Kotagede sub-district at 662,132.

\subsection{Regional Competitiveness Analysis}

Regional competitiveness analysis uses the results of the calculation of shiftshare by looking at the value of the 
Regional Share Growth Component calculation, the Yogyakarta Urban Area is divided into three sectors, namely the primary sector, the secondary sector and the tertiary sector.

\subsubsection{Primary Sector}

The primary sector consists of the Regional Share Growth Component calculation results in the agricultural sector as well as mining and quarrying. Following are the results of an analysis of the competitiveness of the primary sector areas.

Based on the Regional Share Growth Component calculation results, it can be seen from the highest value in the primary sector, namely 5.4808 with a competitive classification. The lowest value for the primary sector is $-3,900$ with a classification of not competitive. The following is a map of the distribution of Yogyakarta Urban Area primary sector competitiveness :

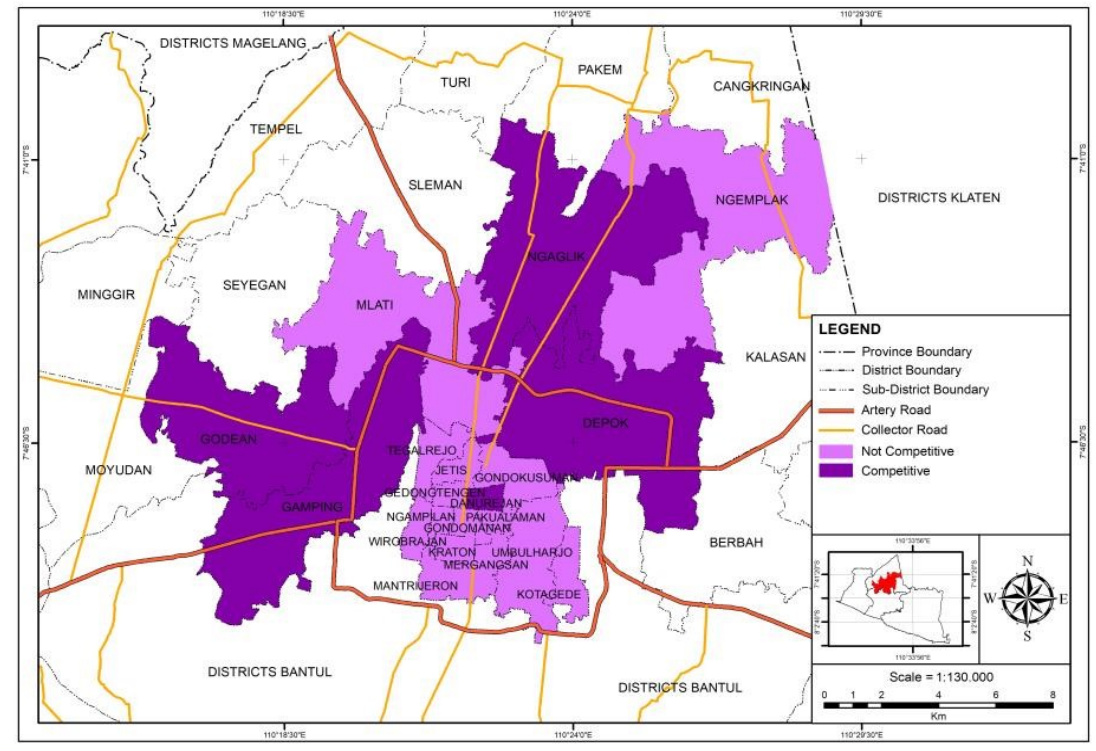

Figure 8 Distribution of primary sector regional competitiveness

Based on the map above, it can be seen that areas with a darker color mean areas that are competitive, while areas with lighter colors mean areas that are not competitive. The downtown area has only one competitive area, namely Danurejan District. Areas with many competitiveness are found in the periphery areas, while the center of Yogyakarta City is more dominant.

\subsubsection{Secondary Sector}

The secondary sector is a combination of the manufacturing sector, the electricity, gas and water supply sector, and the construction sector. Based on the calculation of Regional Share Growth Component, the secondary sector is divided into two, namely competitiveness and non-competitiveness. The following is an analysis of the competitiveness of the secondary sector.

The highest Regional Share Growth Component value in the secondary sector according to the table above is in Ngemplak District with a value of 6.4343 and a competitive classification. The lowest Regional Share Growth Component value is in Kotagede District with a value of -2.5947 and the classification is not competitive. There are 10 sub-districts classified as having no competitiveness, while 10 districts with the classification of competitiveness. The following is a map of the distribution of Yogyakarta Urban Area competitiveness by secondary sector. 


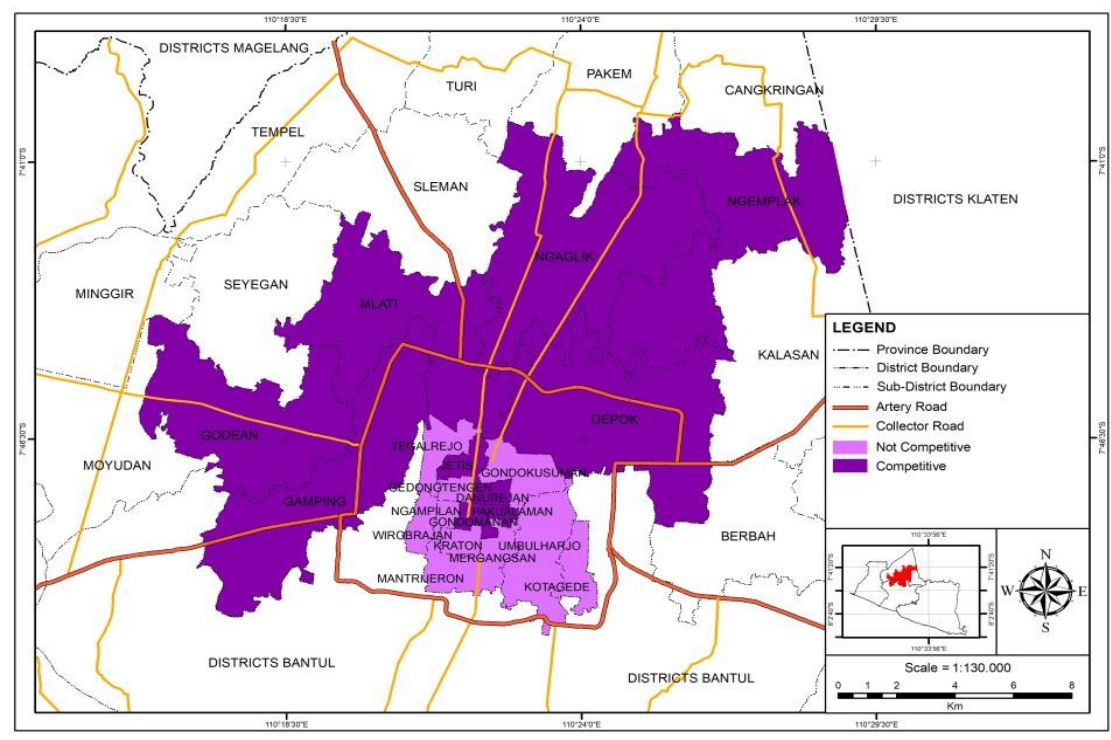

Figure 9 Distribution of secondary sector competitiveness

The competitiveness of the secondary sector with the classification of competitiveness is dominated by areas located on the outskirts of KPY, namely Godean, Gamping, Mlati, Depok, Ngemplak, Ngaglik, Jetis, Danurejan and Pakualaman districts. The distribution of areas classified as uncompetitive areas is in the Kraton, Gondokusuman, Gedongtengen, Umbulharjo, Mantrijeron, Mergangsan, Kotagede, Ngampilan, Wirobrajan, Tegalrejo, and Gondomanan Districts. In [11] and [12], competitiveness is identified with productivity problems, namely by looking at the level of output generated from each input used. Increased productivity caused by an increase in the amount of physical input for capital and labor, an increase in the quality of the inputs used and an increase in technology [13].

\subsubsection{Tertiary Sector}

The tertiary sector of communication includes the trade, hotel and restaurant sector, the transportation sector and the financial sector, leasing and corporate services and the services sector. From the analysis of the competitiveness of the tertiary sector, there are two classifications including areas with competitiveness and non-competitiveness. KPY competitiveness map based on tertiary sector can be seen in the following map :

Based on the Share Growth Component calculation, it can be seen that the highest value of tertiary sector is 21.9508 with a competitive classification. The lowest value for the calculation of the tertiary sector -5.6640 with the classification of not competitive. The highest score for KPPW was in Mlati District, while the lowest score was in Danurejan District. The following is a map of the distribution of competitiveness in the Yogyakarta Urban Area tertiary sector:

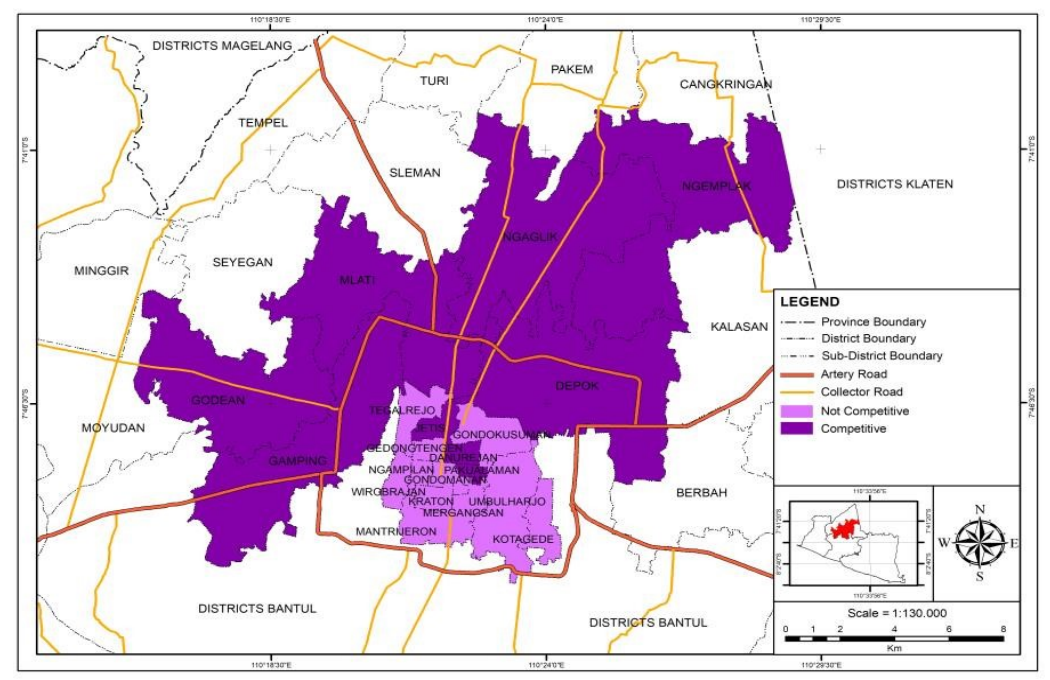

Figure 10 Distribution of tertiary sector competitiveness 
Based on the above classification, it shows that from the tertiary sector, areas with competitiveness are dominated by areas located on the outskirts of Yogyakarta Urban Area, while areas in the city center have a potential classification and are relatively left behind. This condition is the same as the competitiveness of the secondary sector. The competitiveness of the secondary sector with the classification of competitiveness is dominated in the interior areas including Godean, Gamping, Mlati, Depok, Ngemplak, Ngaglik, Jetis, Danurejan and Pakualaman districts. The distribution of areas classified as incompetent areas is in the city center, namely in the Kraton, Gondokusuman, Gedongtengen, Umbulharjo, Mantrijeron, Mergangsan, Kotagede, Ngampilan, Wirobrajan, Tegalrejo, and Gondomanan Districts.

Analysis of regional competitiveness based on economic performance shows that there has been a shift in the function of Yogyakarta City as a center / concentration of economic activity growth which tends to be uncompetitive to shift to hinterland areas with competitive secondary and tertiary sectors. Competitiveness is one of the main issues in regional development because competitiveness secures the sustainable growth of local welfare and prosperity [5]. Thus, to increase the competitiveness of regional economies, it is necessary to develop regional economic centers based on local potential [6].

\section{CONCLUSION}

The spatial development of the Yogyakarta urban area leads to the hinterland area in the north, which is spread over the districts of Ngaglik, Depok, Gamping, Godean, Mlati, and Ngemplak. This spatial development is characterized by a high population growth rate in the hinterland region, namely in Ngaglik (3.38\%), Mlati (2.21\%), Gamping $(2.14 \%)$, and Ngemplak $(2.05 \%)$ Districts. In addition, accessibility is crucial in encouraging urban development [7].

Changes in land use developed in 2014-2018 showed an increase of 251 ha. The changes that occur are changes from agricultural land to changing functions into settlements as well as trade and services.

The economic competitiveness of urban areas in Yogyakarta from the results of shiftshare calculations shows that the primary, secondary and tertiary sectors are dominated in the hinterland region. The downtown areas tend to be classified as areas that are not competitive. Economic inequality in the urban Yogyakarta area is high, namely 0.96 and has increased for 3 years (20122016).

Based on the results of the analysis, the direction of spatial development and regional economic competitiveness is dominated by the hinterland or the outskirts of the Yogyakarta city. This is influenced by the high population growth rate, the rapid development of developed land, and conditions of high economic inequality.

It is necessary to have spatial and economic integration in income distribution. The regional development pattern is integral, which is an integration of the areas covered by the region through an equality approach [8].

Spatial integration focuses more on strengthening the functions of the center and subcenter of economic activity in order to be able to support economic activity and also to strengthen the interaction between the center and sub-centers of economic activity in order to be able to provide mutual services to the downtown area and also its hinterland.

Economic integration focuses on balancing economic activities and strengthening the flow of commodities in the form of raw materials and marketing. A balance of economic activity and strengthening of commodity flows can be planned by utilizing local potential to increase regional income.

\section{ACKNOWLEDGMENTS}

Our thanks go to DRPM Kemenristek / BRIN for providing assistance in the form of PDP grants, and LPPM University of Technology Yogyakarta who have assisted in the research and publication process.

\section{REFERENCES}

[1] Sugiri, A., I. Buchori and S. Soetomo 2011. Sustainable Metropolitan Development: Towards An Operational Model for Semarang Metropolitan Region, The International Journal of Environmental, Cultural, Economic and Social Sustainability, Vol 7 (5), 301-23.

[2] Badan Pusat Statistik Kota Yogyakarta. 2017. Yogyakarta dalam Angka 2017. Yogyakarta : Badan Pusat Statistik.

[3] Hadi, Sabari Yunus, 2010. Metode Penelitian Wilayah Kontemporer, Cetakan Pertama. Yogyakarta: Penerbit Pustaka Pelajar.s

[4] Yeo, Benjamin J.K., 2010, Driving the Knowledge Economy : Explaining the Impact of Regional Innovation Capacity on Economic Performance, Contemporary Management Research Pages 71-86, Vol. 6, No. 1, March 2010. Adisasmita, Rahardjo. 2005. DasarDasar Ekonomi Wilayah. Penerbit Graha Ilmu.

[5] Hassan, Mohd Khairul Hisyam, Zakariah Abdul Rashid, Khalil Abdul Hamid (2011), East Coast Economic Region From The Perspective of Shift- 
Share Analysis, International Journal of Business and Society, Vol. 12, No. 1, 2011, 79-88.

[6] Brown S. 2003. Spatial analysis of socioeconomic issues: gender and GIS in Nepal. The International Journal of Geovisualization and Spatial Analysis, 23(4):338-344..

[7] Banerjee, Polash, 2019. Identification of Essential Descriptors in Spatial Socioeconomic Impact Assessment Modeling: a Case Study of Highway
Broadening in Sikkim Himalaya. The International Journal of Geovisualization and Spatial Analysis, Vol 6:2333-2354

[8] Ibrahim A, El-Anwar O, Marzouk M. 2018. Socioeconomic impact assessment of highly 3 dense-urban construction projects. he International Journal of Geovisualization and 4 Spatial Analysis, Vol 92:230-241. 